\title{
FLOWERING PLANTS OF Hedera helix L. IN THE GRUNWALD DISTRICT OF THE CITY OF POZNAŃ
}

\author{
Korszun Stanisława, Bykowska Joanna \\ Department of Dendrology and Nursery, Faculty of Horticulture, Poznań University of Life Sciences, \\ Baranowo, ul. Szamotulska 28, 62-081 Przeźmierowo, Poland, \\ e-mail:kdis@up.poznan.pl
}

Received: 16.11.2010

\begin{abstract}
In the period from September 2008 to July 2009 in the Grunwald district in the city of Poznań, Poland, a total of 609 localities of flowering English ivy were recorded, for which 769 plants were described. These plants were found in different localities, most of them euhemerobic. The biggest number of flowering specimens was recorded in home gardens. Support for climbing plants was mainly provided by trees and shrubs, including fruit trees - pear and apple trees. Among the other tree species, the biggest group comprises Scots pine, common birch, European larch and common locust. Other types of supports included fences, buildings and elements of small architecture. A very high number of specimens in the generative stage in the Grunwald district indicates considerable popularity and at the same time very good adaptation of ivy not only to the climatic conditions of the city of Poznan, but also to anthropogenic changes in the habitat.
\end{abstract}

Key words: English ivy, Poznań-Grunwald, inventory of flowering plants, chorological analysis

\section{INTRODUCTION}

English ivy (Hedera helix L.) is a Mediterranean-Atlantic species (Browicz and GostyńskaJaku szewska, 1969) and it is considered a Tertiary relic (S z a fer, 1964; Ć w ik li ńs ki, 1974). In the flora of Poland, it is the only representative of the family Araliaceae and the only evergreen liana (Browicz and Gostyńska-Jakuszewska, 1969). The natural range of ivy covers western, central and southern Europe and rather limited areas of southwestern Asia and northern Africa. Poland is located at the north-western part of this range (M e u s el et al. 1978; B o r a ty ń s k a , 1987).
Ivy grows over almost the entire area of Poland, but is found much more frequently in the west and south of the country. The closer a given area is situated to the eastern or northeastern border of the country, the less often ivy is found ( $\mathrm{J}$ a s i e w i c z, 1951; B i a ł o bok and Hellwig, 1955; Browicz and Gos t y ń s ka - J a ku sze w s ka, 1969; B or a tyńs ka, 1987). In natural localities, it grows most frequently in broadleaved forests, particularly beech forests (B ro wicz and Gostyńska-Jakuszewska, 1969; Seneta, 1996) and it is partially protected (the official Journal of Law "Dziennik Ustaw" of 2004 no. 92, item 880, "Dziennik Ustaw" of 2004 no. 168, item 1764).

Among other plants, English ivy is distinguished by polymorphism of its shoots and leaves. Shoots may creep on the ground surface or with trailing roots climb over supports up to 20 (B i a 1 o b o k and Hell w i g, 1955; Seneta and Dolatowski, 2008), occasionally even 26 (H e g i , 1931) and $30 \mathrm{~m}$ (S e n e ta, 1996) height and $33 \mathrm{~m}$ width (H e g i, 1931). The decorative value of this species arises from its evergreen, coriaceous leaves, lobed on non-flowering shoots and rhomboid or ovate on flowering shoots (S e n e $t$ a and Dolat ow ski, 2008). The autumn flowering time in this species is also atypical.

The literature concerning ivy is extensive. For a long time the interest of botanists and dendrologists has been focused on the flowering of ivy, in Poland considered to be a rare phenomenon ( $\mathrm{J}$ a s i e w i c z, 1951; Szafer, 1964; B rowicz and Gostyńska-Jakuszewska, 1969; Ćwiklíński, 1974; Bac i e c z k o et al. 2000). An enormous number of publications concern descriptions of natural localities of flowering and fructiferous specimens of ivy. Scarce studies have been conducted in Polish cities and towns. 
Most information on the subject comes from the city of Szczecin (S t a chak and Zieli ński, 1996; Nowak, 1998; Zieliński, 1998) and its environs (S t a c h a k et al. 1999, 2001). Moreover, results have been published on a survey of ivy localities in the city of Wrocław and its environs (Ś wi e r k o s z, 1994 a and b), Warszawa (Z a le s ka, 1994, 1995), Kraków (M y c zkow ski, 1954), as well as the towns of Barlinek (B a ciec zko et al. 2000) and Gardna Wielka (Kreft, 2006).

Observations of annually flowering and fruitbearing ivy specimens in Poznan suggest that in the capital city of the Wielkopolska region the biggest number of localities is recorded among all the Polish urban areas. This paper presents the results of an inventory of flowering English ivy plants, growing in one of the five administrative districts of Poznan, i.e. Grunwald.

\section{Geographical location and climate of Poznań}

Poznan is one of the oldest cities in Poland as well as the biggest city and, at the same time, the capital of the Wielkopolska region. The city is located in central western Poland, in the central part of the Wielkopolska Province. According to K o n d racki (1994, 2001), Poznań belongs to the macroregion of the Wielkopolskie Lake District. Boundaries of three mesoregions cross the area of the city, i.e. the Poznan Lake District (the western part of the city), the Gniezno Lake District (the eastern part), and the Poznań Water Gap of the Warta River, separating the two (J a c k o w i a k, 1993). The Poznań Old Town, together with the cathedral district, was built on a flood land terrace, in the Warta River valley. The new city centre of Poznań and its western suburbs were developed over the Poznań Plain (K o n d r a c k i, 1994, 2001).

The area of Poznań, as at 31 December 2006, covered $261.9 \mathrm{~km}^{2}$. The geographical location of the most extreme points of the city limits was $52^{\circ} 30^{\prime}$ 'to the north (northern geographic latitude), $52^{\circ} 18^{\prime}$ to the south (northern geographic latitude), $16^{\circ} 48^{\prime}$ to the west (eastern geographic longitude), and $17^{\circ} 04^{\prime}$ to the east (eastern geographic longitude). Poznań extends over a distance of $22 \mathrm{~km}$ from north to south, while from east to west it is $21 \mathrm{~km}$ (The Statistical Yearbook of Poznań, 2007).

The climate of Poznan is mostly identical with the climate of the region. However, local conditions, as in all conurbations, is modified by human activity, e.g. air pollution by smoke, exhaust fumes, industrial gases, dusts as well as the influx of artificially produced heat to the atmosphere.

The Wielkopolska region is located in the transition zone between the continental and maritime climates, which results in considerable variability of the weather. Most frequently masses of humid polar maritime air arrive over the Wielkopolska region from the west, particularly in summer and autumn from the northern Atlantic. They bring cooler weather, increased cloud cover and precipitation in summer and warmer weather, as well as increased cloud cover and periodical thaws in winter. In turn, in spring and winter dry masses of polar continental air are blown over the Wielkopolska region from Asia. They contribute to a reduction in cloud cover. In summer they are responsible for hot and sunny weather, while in winter - for frosty weather with no snow (W oś, 1994; Ł ę c k i , 2004).

Westerly winds, prevalent in summer, and south-western winds, equally frequent in winter, predominate throughout the region (W oś, 1994; Ł ę c k i , 2004). In spring in the area of Poznan easterly winds are prevalent (W os , 1994). The mean wind velocity within the city in 2007 was $3.9 \mathrm{~m} \cdot \mathrm{s}^{-1}$ (The Statistical Yearbook of the Wielkopolska Province, 2008).

Mean annual temperature in Poznań starting from the 1950's has been gradually increasing. In 2006 it was $9.7^{\circ} \mathrm{C}$, while in 2007 it was already $10.0^{\circ} \mathrm{C}$ (The Statistical Yearbook of Poznań, 2007; The Statistical Yearbook of the Wielkopolska Province, 2008). Maximum temperature recorded in Poznan in the years 1971-2007 was $37.0^{\circ} \mathrm{C}$, while minimum temperature was $-28.5^{\circ} \mathrm{C}$. The long-term data from the Institute of Meteorology and Water Management show that July was the warmest month in that city with mean monthly temperature of $20.1^{\circ} \mathrm{C}$ in the years $2001-2007$, while the coldest month was January with mean temperature of $-0.7^{\circ} \mathrm{C}$ (The Statistical Yearbook of the Wielkopolska Province, 2008). The number of freeze days in the years 1951-1980 in Poznań was on average 74 days a year, while the number of frost days with the maximum air temperature below $0^{\circ} \mathrm{C}$ was on average 34 days (Woś, 1994). Considerable differences in temperature are found within the city limits. In parks, in the districts with large green areas and in the suburbs, the temperature is lower and humidity is higher than in the vicinity of streets or the city centre districts, with low plant cover (B u g a ł a et al. 1984).

A significant problem both in Poznan and in the whole Wielkopolska region is the amount of precipitation. Mean annual totals for the region range from below 500 to over $600 \mathrm{~mm}$. The lowest precipitation is recorded in the central part of the region, i.e. in the Gniezno and Poznań Lake Districts (W o ś, 1994; $\mathrm{E}$ ę c k i , 2004). These areas are located in the so-called rain shadow and are frequently referred to as the "dry island" (Ł ę cki, 2004). The long-term mean annual precipitation in those areas usually does not exceed $550 \mathrm{~mm}$ (W o ś, 1994). Annual total precipitation in Poznań varies depending on the year, but a downward trend may be observed. In the 1990's annual total 
precipitation was approx. $550 \mathrm{~mm}$ in the city. In the years 2001-2006, it was as little as $496 \mathrm{~mm}$. Data of the Institute of Meteorology and Water Management indicate that in Poznan the level of precipitation was only $440 \mathrm{~mm}$ in 2006 (The Statistical Yearbook of Poznań, 2007; The Statistical Yearbook of the Wielkopolska Province, 2008). In turn, the year 2007 was characterized by a higher amount of precipitation, i.e. $586 \mathrm{~mm}$ (The Statistical Yearbook of the Wielkopolska Province, 2008). It has been observed in the annual pattern of monthly precipitation totals that the highest amount of rainfall is recorded during summer. In the growing seasons of 1951-1980 from April to September, mean precipitation in Poznań was recorded to be $330 \mathrm{~mm}$ (W o ś, 1994).

Actual insolation in Poznań, similarly as total precipitation, depends on a given year. In 2006 it was 1989 h, while in 2007 it was 1825 h (The Statistical Yearbook of the Wielkopolska Province, 2008).

\section{Characteristics of the study area}

Poznań is divided into 5 districts (Fig. 1). Four of them are located in the left-bank part of the city, i.e. Grunwald, Jeżyce, Stare Miasto and Wilda. In the rightbank part, the district of Nowe Miasto is situated.

Grunwald occupies the south-western part of Poznań (Fig. 1). The name of the district was adopted after WWII after the name of one of the main traffic arteries in that area, i.e. Grunwaldzka Street (Eęcki and Maluśkiewicz, 1998). Grunwald is the third district of the city in terms of its size. In 2005 its area was 3619 ha and constituted $13.8 \%$ of the area of Poznan (The Statistical Yearbook of Poznań, 2007). The boundaries of the district are marked by the following streets: Bukowska, Roosevelta, Przełęcz, Głazowa, Piargowa, Leszczyńska, Pszczyńska, and the railway tracks of the Zbąszynek line and a stream, Strumień Junikowski.

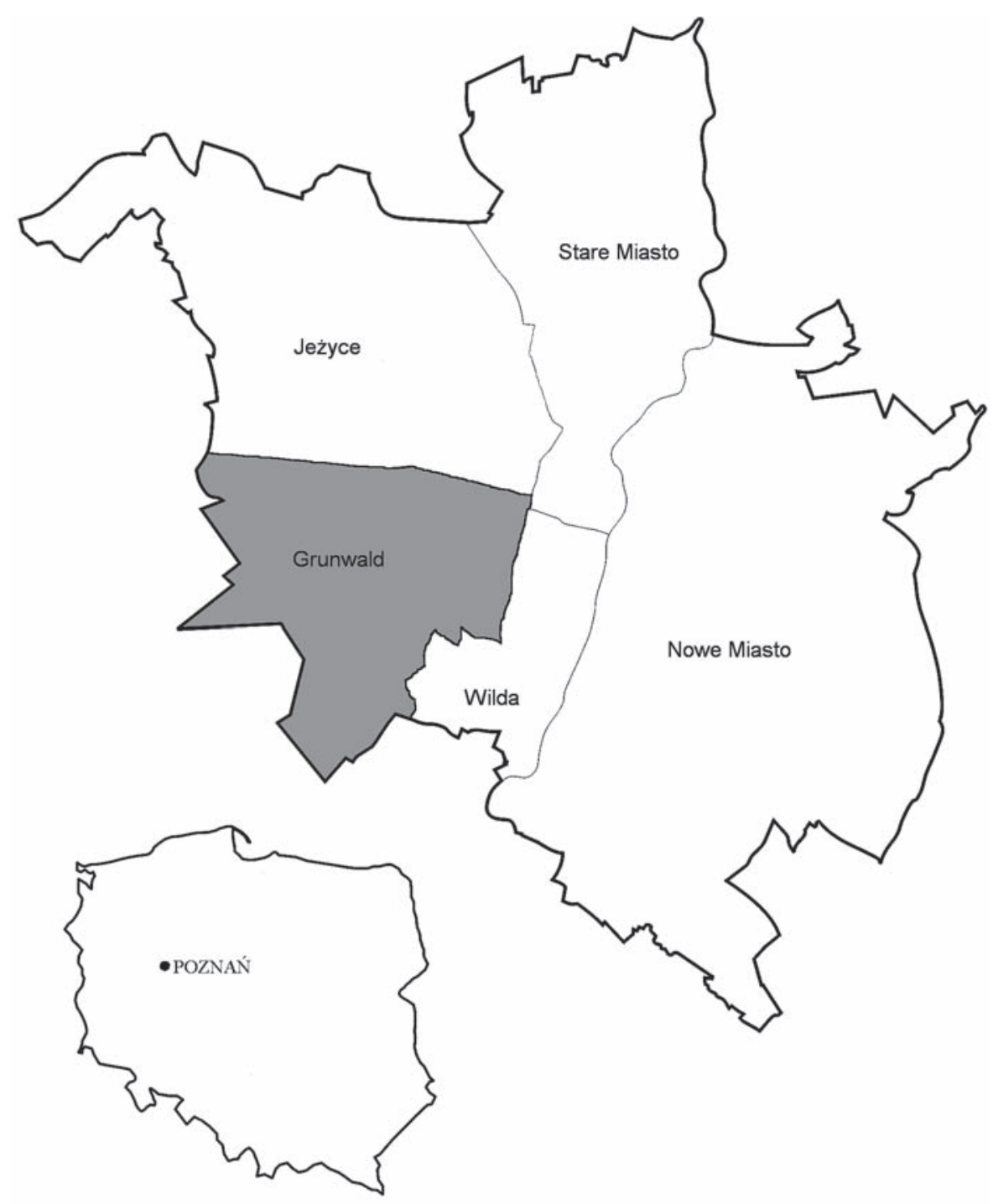

Fig. 1. District division of Poznań territory 


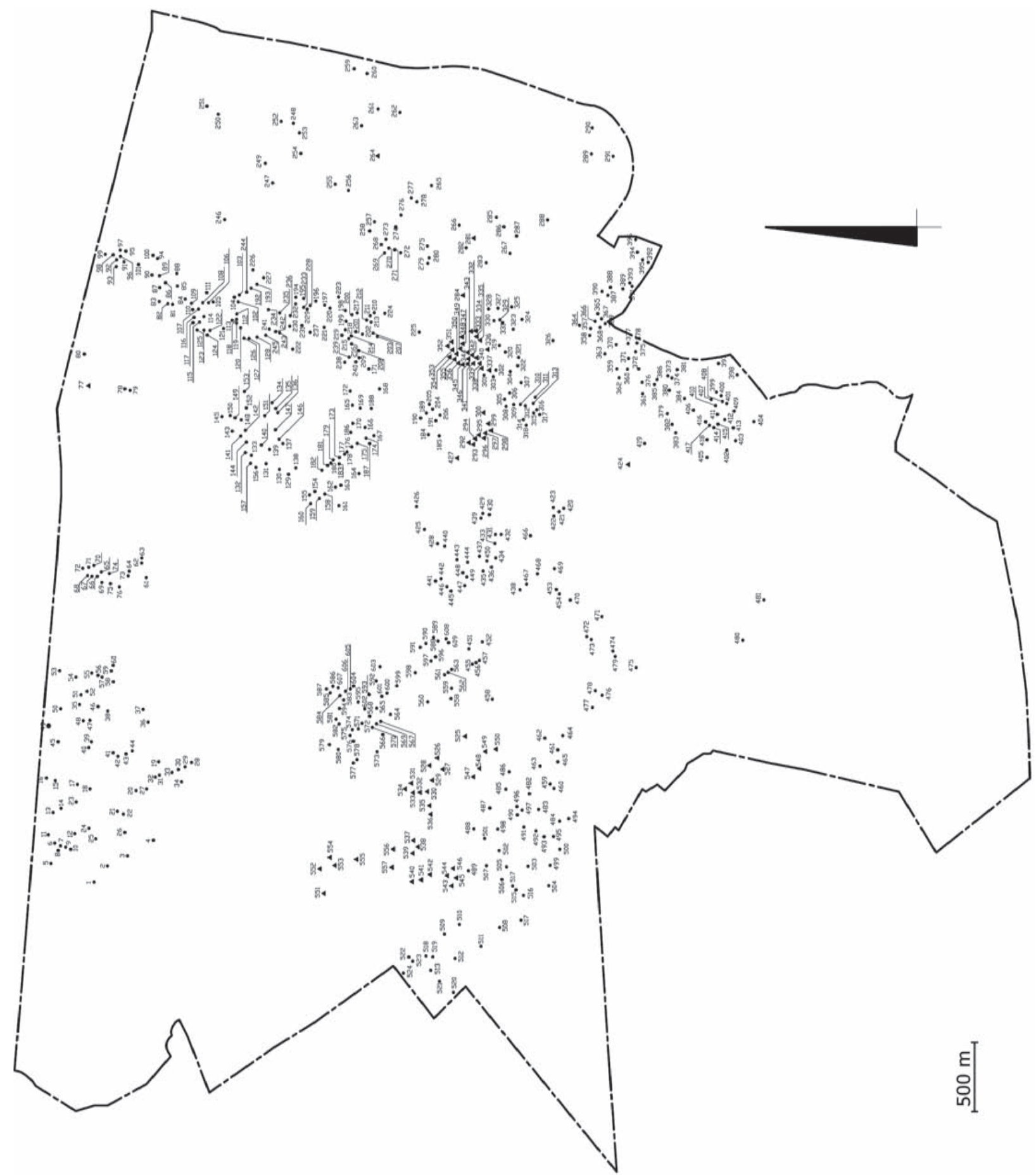

Fig. 2. Distribution of localities of flowering English ivy in the Poznań-Grunwald district $(\bullet-$ euhemerobic habitats, $\Delta$ - polyhemerobic habitats)

The Grunwald district in the most part is a housing district, despite the fact that several big industrial plants are located in that part of town. There are 11 residential or housing estates in this area, commonly referred to as districts. These are: Fabianowo, Górczyn, Junikowo, Kopanina, Kotowo, a part of Ławica, Łazarz, Marcelin, Osiedle Kopernika, Osiedle Kwiatowe and Raszyn.
Fabianowo, Górczyn, Junikowo, Kotowo, Ławica and Łazarz are former villages located in the vicinity of Poznań; in the past they were owned by the Poznań chapter or constituted parts of knights' demesne or the Crown lands. They are located at the south-western or western boundary of the city. Górczyn and Łazarz were incorporated into the administrative boundaries of Poznań in 1900, while the four other 
villages were incorporated in 1940 . These "districts" in the most part are covered by housing or residential development. It comprises detached, semi-detached and terraced houses. Among the newly erected buildings, single houses from the turn of the 19th and 20th centuries are preserved as well as buildings of the former farms. Up to the present, in Górczyn the former rural system of roads and remnants of village development are preserved. In front of the railroad viaduct at Głogowska Street, the first housing estate comprehensively designed and erected in Poznań after Poland regained independence after WWI was built in the years 1925-28. In mid-1970's, west of Głogowska Street, a large housing estate was built, comprising 11-storey high-rises.

The areas adjacent to Grunwaldzka Street were developed in the period between the World Wars. In the 1950's a housing estate of semi-detached houses was built along Grunwaldzka Street, from Kasztelanów to Bułgarska streets. In the years 1958-1964 the construction of another estate, Osiedle Grunwald, was financed from the funds of the city budget within the area of Bułgarska, Grunwaldzka, Marszałkowska and Rycerska streets. The estate comprised 40 buildings for over 5 thousand people. In the years 1961-1970, north of Osiedle Grunwald, between Bułgarska, Bukowska, Szamotulska and Rycerska streets, the Priest Jerzy Popiełuszko estate (the former Świerczewski estate) was erected. The estate is composed of 130 buildings, mostly of 5 storeys, erected from prefabricated units for approx. 22 thousand inhabitants ( $\mathrm{E}$ ęcki and $\mathrm{Ma}$ 1 u śk i e w i c z, 1998).

Industrial and warehouse facilities may be found at Grunwaldzka Street, in Junikowo, in the vicinity of Jeleniogórska, Wołowska and Wieruszowska streets as well as in Łazarz.

In the Grunwald district there are several parks, 5 allotment garden complexes, and two cemeteries. At the edge of Górczyn and Raszyn, in Ściegiennego Street, the Górczyn Cemetery is located. In the western part of Junikowo, one of the biggest municipal cemeteries, not only for Poznań, but on the national scale, is situated, covering an area of over 90 hectares.

\section{METHODS}

The survey of flowering specimens of English ivy in the Poznań district of Grunwald was conducted in the period from September 2008 to July 2009. Localities were marked on the basis of field observations, taking into consideration sites visible for a passer-by walking on the pavement. One locality was treated as a distinctly limited area, most often a housing property, having a specific location and name, e.g. address. In bigger areas, such as cemeteries or parks, ivy plants growing at a considerable distance were considered as separate localities. One specimen was considered to be ivy shoots climbing over a single support or a set of supports (e.g. in case of very densely planted trees or shrubs). All localities were numbered and marked on the city plan of Poznań using AutoCAD 2007 software. The plan was prepared at a 1:10 000 scale on the basis of the city map of Poznań prepared by B r z e z i ń s k i et al. published in 2008.

On each locality climbers were counted and the following were measured:

- height and width of plants [m] using a LEICA DISTO ladar,

- shoot circumference at a height of $30 \mathrm{~cm}$ from the ground $[\mathrm{cm}]$.

Some plants could not be measured for different reasons, e.g. due to a lack of access to a property and too big a distance of the specimen from the property boundary.

Specimens forming their own crowns, growing in the form of a shrub, and cv. 'Goldheart' were marked. Each time the abundance of flowering was recorded for individual specimens, according to the following scale:

- poor flowering - flower cover below $25 \%$ of plant surface,

- abundant $-25-75 \%$,

- highly abundant - over $75 \%$ plant surface.

The type of support was recorded for each locality: the type of fence taking into consideration the material from which it was made, the species of the tree or shrub over which ivy shoots were climbing (the nomenclature was adopted after Seneta and Dola t o w s k i , 2008), as well as the type of buildings or small architecture. Longitude and latitude of plant localities was determined using GPS satellite navigation.

For the purpose of chorological analysis of ivy in the Grunwald district in Poznań, the scale of hemeroby degrees according to Sukopp, as interpreted by J a c k o w i a k (1990, 1993), was applied. In this scale, 6 degrees of hemeroby are distinguished, depending on the intensity of the impact of anthropogenic factors on ecosystems. Euhemerobic habitats, dominant in the city, were identified in the Poznan-Grunwald district. These included home gardens, parks, areas around tenement houses and blocks of flats (intensively used lawns, housing estate tree and shrub plantings) as well as ruderal localities. Moreover, polyhemerobic localities were distinguished, on which the impact of anthropogenic factors is constant and very strong. These included cemeteries and parking lots.

Moreover, localities of flowering English ivy were analyzed in terms of the land use forms, i.e. spatial complexes (J a c k o w i a k, 1990). 


\section{RESULTS}

In the Poznan-Grunwald district, a total of 609 localities were found, on which 769 flowering plants of English ivy were growing. The distribution of localities is presented in Fig. 2. Out of the total number of climbers, as many as 203 plants formed their own crowns. Apart from the nominal species, four flowering specimens of cv. 'Goldheart' were found. Three of them flowered highly abundantly and one - abundantly.

The height of inventoried specimens ranged from $0.6 \mathrm{~m}$ at locality no. 234 to $13.4 \mathrm{~m}$ at locality no. 437/1. The tallest climber climbed over a European larch, it was $3 \mathrm{~m}$ wide, formed its own crown and flowered highly abundantly. A detailed inventory of all localities and descriptions of climbers are found in the documentation of the Department of Dendrology and Nursery Production.

\section{Characteristics of supports}

In the analyzed area, individual ivy specimens climbed over various supports (Table 1). Most frequently, they were trees and shrubs, both angio- and gymnospermous. They comprised $35.0 \%$ of all supports. Numerous supports were fences $(26.2 \%)$ and various types of buildings (25.7\%), followed by stumps left after cut trees $(4.7 \%)$ and elements of small architecture (4.2\%).

Out of all inventoried flowering ivy specimens, five grew as shrubs - at localities nos. 184/2, 195, 234, 237/3 and 333 .

Trees and shrubs most frequently constituted supports for inventoried flowering ivy specimens. A total of 273 lianas climbed over 278 plants. A list of individual taxa is presented in Tables 2 and 3. Angiospermous trees and shrubs, represented by 33 taxa belonging to 23 types, were supports for 166 climbers (Table 1 and 2). Gymnospermous trees and shrubs (16 taxa from 10 types) were supports for 112 ivy specimens (Table 1 and 3).

Among the above mentioned taxa of "support" trees and shrubs from the class of angiospermous plants, flowering ivy was most often found on fruit trees: pear (27 trees) and apple trees (26). Among ornamental angiospermous species, frequent supports for climbing ivy shoots were common birch (21 trees) and white locust (16 trees), while among gymnospermous species it was Scots pine (27 trees) and European larch (21 trees) - Table 2 and 3.

A total of 208 specimens of English ivy climbed over different types of fences. This climbing species was planted most commonly at such fences as walls (80 localities) and those made from wire nets (73 localities). Moreover, flowering ivy was also observed on fences made from metal bars (23 localities) and on wooden fences (22 localities). The least common types of fence supports were concrete walls (8 localities) and metal sheet fences (2 localities) - Table 1 .
For 204 flowering English ivy plants, different types of buildings constituted their supports (Table 1). Almost $65 \%$ of objects were included into the group of housing and non-housing buildings (apart from residential homes, blocks of flats, farm buildings, a shop, and a workshop were included here). A separate group comprised garages as well as terraces and verandahs.

Small architecture as support was recorded for 33 inventoried ivy specimens. Among the found elements of small architecture, there were trellises, bowers, arches, and a garden gate (Table 1).

\section{Characteristics of flowering English ivy}

In the Grunwald district, a total of 769 flowering ivy specimens were described. Most of them, i.e. 286 (37\%), were characterized by very abundant flowering (75-100\% of plant surface covered with inflorescences), 279 plants flowered abundantly (25-75\% of plant surface covered with inflorescences), while 204 flowered poorly (less than $25 \%$ of plant surface covered with inflorescences).

The information obtained from the owners of real properties on which ivy was in the generative stage shows that some of ivy plants started to produce flowers between the $6^{\text {th }}$ and $15^{\text {th }}$ year of cultivation.

\section{Chorological analysis of localities}

In the analyzed area, English ivy in the generative stage was found mostly in euhemerobic habitats, and to a lesser extent in polyhemerobic habitats. In 536 euhemerobic localities, a total of 693 plants were inventoried. In contrast, only 76 flowering specimens were recorded in 73 polyhemerobic localities (Table 4).

Taking into consideration the division of habitats in terms of the land management, complexes the following types were distinguished in the PoznańGrunwald district: garden-residential complex, park complex, tenement house complex, block of flats complex (modern architecture), transport facilities complex, intermediate complex (forts), cemetery complex as well as ruderal habitats. In the Grunwald district a vast majority of localities and specimens of flowering English ivy was found in the garden-residential complex. These included 524 localities with 670 specimens. In view of the fact that in this district a large proportion of land management is connected with parks, the small number of flowering plants growing in those places is surprising. In turn, a large number of flowering specimens (61 plants) was found in the cemetery complex, which is connected with the presence of two cemeteries in this district. In the Górczyn Cemetery 25 localities were described, while in the Junikowo Municipal Cemetery there were 33 localities. Single localities of flowering ivy were found in the park, tenement house, block of flats, transport facilities complexes as well as ruderal localities (Table 4). 
Table 1.

Characteristics of objects constituting supports for shoots of flowering English ivy specimens in inventoried localities in the Poznan-Grunwald district

\begin{tabular}{|c|c|c|}
\hline Types of supports & $\begin{array}{l}\text { Percentage in total } \\
\text { number of supports }\end{array}$ & $\begin{array}{l}\text { Number of a given } \\
\text { type of support }\end{array}$ \\
\hline $\begin{array}{l}\text { Trees and shrubs, including: } \\
\text { angiospermous } \\
\text { gymnospermous }\end{array}$ & 35.0 & $\begin{array}{l}278 \\
166 \\
112 \\
\end{array}$ \\
\hline $\begin{array}{l}\text { Fences, including: } \\
\text { walls } \\
\text { wire nets } \\
\text { metal bars } \\
\text { wooden } \\
\text { concrete } \\
\text { metal sheets }\end{array}$ & 26.2 & $\begin{array}{r}208 \\
80 \\
73 \\
23 \\
22 \\
8 \\
2 \\
\end{array}$ \\
\hline $\begin{array}{l}\text { Buildings } \\
\text { housing and non-housing buildings } \\
\text { garages } \\
\text { terraces and verandahs }\end{array}$ & 25.7 & $\begin{array}{r}204 \\
132 \\
68 \\
4\end{array}$ \\
\hline Stumps left after felled trees & 4.7 & 37 \\
\hline $\begin{array}{l}\text { Elements of small architecture } \\
\text { trellises } \\
\text { bowers } \\
\text { garden arches }\end{array}$ & 4.2 & $\begin{array}{r}33 \\
18 \\
8 \\
1\end{array}$ \\
\hline $\begin{array}{l}\text { Poles } \\
\text { wooden } \\
\text { concrete } \\
\text { metal }\end{array}$ & 1.6 & $\begin{array}{r}14 \\
1 \\
12 \\
1\end{array}$ \\
\hline $\begin{array}{l}\text { Other supports } \\
\text { frames } \\
\text { railings } \\
\text { low walls } \\
\text { tombstones } \\
\text { ruins of houses } \\
\text { lamp posts }\end{array}$ & 2.6 & $\begin{array}{r}21 \\
1 \\
1 \\
13 \\
3 \\
2 \\
1\end{array}$ \\
\hline
\end{tabular}

Table 2.

Proportions of individual taxa of angiospermous trees and shrubs in their total number

\begin{tabular}{clcc}
\hline Lp. & Species constituting support for English ivy & No. of trees & Percentage \\
\hline 1. & Fruit tree - pear tree (Pyrus sp.) & 27 & 16.3 \\
\hline 2. & Fruit tree - apple tree (Malus sp.) & 26 & 15.7 \\
\hline 3. & Betula pendula Roth & 21 & 12.7 \\
\hline 4. & Robinia pseudoacacia L. & 16 & 9.6 \\
\hline 5. & Juglans regia L. & 14 & 8.4 \\
\hline 6. & Fruit tree - cherry tree (Prunus sp.) & 8 & 4.8 \\
\hline 7. & Fraxinus excelsior L. & 7 & 4.2 \\
\hline 8. & Syringa vulgaris L. & 6 & 3.6 \\
\hline 9. & Populus nigra L. 'Italica' & 5 & 3.0 \\
\hline 10. & Rhus typhina L. & 4 & 2.4 \\
\hline 11. & Acer negundo L. & 3 & 1.8 \\
\hline 12. & Acer platanoides L. & 3 & 1.8 \\
\hline 13. & Tilia cordata Mill. & 3 & 1.8 \\
\hline
\end{tabular}


Tab. 2

\begin{tabular}{|c|c|c|c|}
\hline Lp. & Species constituting support for English ivy & No. of trees & Percentage \\
\hline 14. & Sorbus aucuparia L. & 2 & 1.2 \\
\hline 15. & Fruit tree - plum tree (Prunus sp.) & 2 & 1.2 \\
\hline 16. & Populus nigra L. & 2 & 1.2 \\
\hline 17. & Berberis vulgaris $\mathrm{L}$. & 1 & 0.6 \\
\hline 18. & Fruit tree - peach tree (Prunus sp.) & 1 & 0.6 \\
\hline 19. & Fagus sylvatica L. 'Dawyck' & 1 & 0.6 \\
\hline 20. & Prunus padus L. & 1 & 0.6 \\
\hline 21. & Forsythia $\mathrm{x}$ intermedia Zabel & 1 & 0.6 \\
\hline 22. & Crataegus monogyna Jacq. & 1 & 0.6 \\
\hline 23. & Sorbus aria $(\mathrm{L}$.$) Crantz$ & 1 & 0.6 \\
\hline 24. & Castanea sativa Mill. & 1 & 0.6 \\
\hline 25. & Aesculus hippocastanum L. & 1 & 0.6 \\
\hline 26. & Acer pseudoplatanus L. & 1 & 0.6 \\
\hline 27. & Ligustrum vulgare L. & 1 & 0.6 \\
\hline 28. & Fruit tree - apricot tree (Prunus sp.) & 1 & 0.6 \\
\hline 29. & Morus alba $\mathrm{L}$. & 1 & 0.6 \\
\hline 30. & Pterocarya fraxinifolia (Poir.)Spach & 1 & 0.6 \\
\hline 31. & Populus alba $\mathrm{L}$. & 1 & 0.6 \\
\hline 32. & Populus simonii Carričre & 1 & 0.6 \\
\hline \multirow[t]{2}{*}{33.} & Salix x sepulcralis Simonk. 'Chrysocoma' & 1 & 0.6 \\
\hline & & 166 & 100 \\
\hline
\end{tabular}

Table 3.

Proportions of individual taxa of gymnospermous trees and shrubs in their total number

\begin{tabular}{|c|c|c|c|}
\hline Lp. & Species constituting support for English ivy & No. of trees & Percentage \\
\hline 1. & Pinus sylvestris $\mathrm{L}$. & 27 & 24.1 \\
\hline 2. & Larix decidua Mill. & 21 & 18.8 \\
\hline 3. & Thuja occidentalis L. & 16 & 14.3 \\
\hline 4. & Picea pungens Engelm. 'Glauca' & 13 & 11.6 \\
\hline 5. & Picea abies (L.)H.Karst. & 8 & 7.1 \\
\hline 6. & Pseudotsuga menziesii (Mirb.)Franco & 6 & 5.4 \\
\hline 7. & Pseudotsuga menziesii var. glauca (Mayr)Franco & 5 & 4.5 \\
\hline 8. & Abies alba Mill. & 5 & 4.5 \\
\hline 9. & Taxus baccata $\mathrm{L}$ & 2 & 1.8 \\
\hline 10. & $\begin{array}{l}\text { Chamaecyparis lawsoniana (A.Murray bis)Parl. } \\
\text { 'Alumii' }\end{array}$ & 2 & 1.8 \\
\hline 11. & Juniperus virginiana $\mathrm{L}$. & 2 & 1.8 \\
\hline 12. & Platycladus orientalis (L.)Franco & 1 & 0.9 \\
\hline 13. & Juniperus sabina $\mathrm{L}$. & 1 & 0.9 \\
\hline 14. & Juniperus virginiana L. 'Glauca' & 1 & 0.9 \\
\hline 15. & Abies concolor (Gordon et Glend.)Lindl. ex Hildebr. & 1 & 0.9 \\
\hline \multirow[t]{2}{*}{16.} & Pinus nigra J.F.Arnold & 1 & 0.9 \\
\hline & & 112 & 100 \\
\hline
\end{tabular}


Table 4

Proportions of localities of ivy in individual habitats

\begin{tabular}{lccc}
\hline \multirow{2}{*}{$\begin{array}{c}\text { Land } \\
\text { use complexes }\end{array}$} & $\begin{array}{c}\text { Degree of habitat } \\
\text { hemeroby }\end{array}$ & \multicolumn{2}{c}{ No. of } \\
\cline { 3 - 4 } Garden-residential & euhemeroby & 524 & 670 \\
\hline Park & euhemeroby & 1 & 4 \\
\hline Tenement houses & euhemeroby & 4 & 4 \\
\hline Blocks of flats & euhemeroby & 5 & 5 \\
\hline Ruderal localities & euhemeroby & 2 & 10 \\
\hline Transport facilities & polyhemeroby & 6 & 6 \\
\hline Cemetery & polyhemeroby & 58 & 61 \\
\hline Intermediate (fortifications) & polyhemeroby & 9 & 9 \\
\hline Total & & $\mathbf{6 0 9}$ & $\mathbf{7 6 9}$ \\
\hline
\end{tabular}

\section{DISCUSSION}

English ivy has been grown since ancient times. It is one of the oldest ornamental plant species planted in parks as a climber, a plant used for cover, but also a greenhouse plant and one used to decorate rooms ( $\mathrm{kukasiewicz}$, 1986/1987). Ivy is frequently found in cultivation, particularly on walls of old buildings, stems of park trees and different fences. Due to the cover properties, it is planted in home gardens, parks and cemeteries (B row i c z and Gosty ńs ka Jaku s zew ska, 1969; N owak, 1998; Zi e li ínski, 1998; S tachak et al. 1999, 2001).

Most of the studies conducted to date in Poland on the occurrence of flowering and fruit-bearing ivy specimens concerned natural localities. This problem has attracted interest of researchers, as it was commonly believed that under Polish conditions ivy blooms rarely. According to H e g i (1931), young specimens begin their generative development as early as after 8-10 years. In turn, S e n e t a and D ol a tow ski (2008) reported that flowers and fruits are formed on specimens as old as several decades. Although the climber is characterized by considerable shade tolerance, in order to bloom, plants require large amounts of light. Thus, flowering of ivy is observed high in tree crowns (Białobok and Hellwig, 1955; Browicz and Gostyńska-J aku szew ska, 1969; S e ne ta, 1996; S eneta and Dolatowski, 2008).

According to B o r a t y ń s k a (1987), the distribution of natural localities of flowering and fruit-bearing English ivy confirms the opinion that flowering of this species is limited to the highest degree by climatic conditions, particularly autumn ground frost and early winter frost. It is the period when ivy is still fully developed. Thus, the optimal locality would be a warm site, shielded from wind, with northern, western or eastern exposure, and fertile, lime soils (B r o w i c z and
Gos t y ń s k a - J a ku s ze w s ka, 1969; B o r a t y ń $\mathrm{s} \mathrm{k} \mathrm{a,} \mathrm{1987).} \mathrm{Southern} \mathrm{exposure} \mathrm{is} \mathrm{least} \mathrm{advantageous}$ for flowering, since in such localities ivy is exposed to considerable fluctuations of temperatures and freezing (Ć́wikl ińs ki, 1974; B or a ty ńs ka, 1987).

Up to 1987,144 natural localities of flowering ivy specimens were described in Poland (B or a t y ń ska, 1987). In the opinion of the cited author, considerable problems are encountered when determining the range of a locality of flowering ivy due to their dispersal and difficulties with identification of their origin. According to Olaczek (1979), this boundary crosses almost the centre of Poland, while flowering of ivy is observed more frequently on its western side. A list of natural localities indicates that clusters of flowering and fruit-bearing ivy plants are found mostly in the Western Pomerania, particularly in the Szczecin region, as well as the Central Polish Uplands, the Kujawy region, the Kraków-Częstochowa Jura and the Carpathian Foothills as well as the $\mathrm{Su}$ deten Foothills and Foreland (B o że k, 1979; B o ratyńs ka, 1987).

While the above observations concern localities of natural origin, they well correspond to the findings concerning flowering of ivy in urbanized areas. The biggest body of information on anthropogenic localities of flowering ivy specimens comes from the northwestern, central and western Poland, particularly the Szczecin region. Studies on the occurrence of ivy flowering in Szczecin were conducted, e.g., by $\mathrm{S} \mathrm{t} \mathrm{a} \mathrm{c} \mathrm{h} \mathrm{a} \mathrm{k}$ and Zieliński (1996), Nowak (1998), Zie li ńs ki (1998), in the surroundings of churches and village cemeteries in the southern part of the Szczecin Lowland by $\mathrm{S} \mathrm{tach} \mathrm{ak}$ et al. (1999), while in the former Szczecin province by Ć w i k l i ń s k i (1974).

A survey of 609 localities in the Grunwald district in Poznań with specimens of English ivy flowering annually indicates the high popularity of this spe- 
cies. Similar observations from Szczecin were given by $\mathrm{Stachak}$ et al. (1999), while from Wrocław by Ś w i e r k os z (1994a). The number of localities also indicates very good adaptation of the climber to the climatic conditions (Poznan lies at the boundary of the natural range of this species) and habitats in the Grunwald district. In an area covering 3619 ha, as many as 769 flowering specimens were recorded. In Wrocław, in the entire city area, Ś wi e rk o s z (1994a) found only 253 plants in the generative stage.

The results recorded by the authors of this study confirm earlier findings that English ivy is resistant to different types of air pollution. Under conditions found in Poznań, this species is considered one of the most valuable cover plants with very high decorative value throughout the year, exhibiting very high life scale in relation to light and moisture conditions ( $\mathrm{u} \mathrm{k}$ a s i e w i c z, 1986/1987). J a c k ow i ak (1990) included English ivy in the group of apophytes, i.e. plants exhibiting adaptability of local populations to habitat conditions changing under the impact of anthropopressure. In conditions found in Poznań, ivy performs well as a plant providing both vegetation cover and a climber. It grows very well in sites strongly transformed by human activity - in euhemerobic or even polyhemerobic localities. Almost $1 / 4$ inventoried ivy specimens grew over building walls, which is very important in the city where the area is hard to manage.

The number of localities (609) and flowering specimens (769) described in only one district of Poznań is the highest in comparison to data reported from other Polish cities. Ś wierk os z (1994a) reported only 100 localities of ivy in the entire area of Wrocław. In 48 of these localities, 253 generative specimens were found. In Warsaw Z a le s k a $(1994,1995)$ recorded 15 localities with 21 flowering and fruit-bearing plants. In Kraków observations of fruit-bearing ivy were recorded by Myczkowski (1954). This author found 1 specimen. In Szczecin N ow ak (1998) described flowering ivy in 52 localities in 13 right-bank city districts (excluding parks and cemeteries). In left-bank Szczecin, in home gardens and around public buildings Zi e li ńs ki (1998) recorded 197 flowering and fruit-bearing specimens. In turn, $\mathrm{Stach} \mathrm{ak}$ and $\mathrm{Zie}$ 1 i ń s k i (1996) inventoried 278 flowering climbers in localities in the parks and cemeteries in Szczecin. In the Pomerania region two pieces of information were presented in the literature on flowering specimens of ivy in cities. In the town of Barlinek, covering an area of 17.54 ha, B acieczko et al. (2000) identified 223 localities of ivy in the generative stage, of which as many as 190 were growing in the municipal wood. In turn, K r e f t (2006) conducted studies in the town of Gardna Wielka. In an area of 1095.15 ha, this author recorded 3 localities (the municipal cemetery, the former evangelical cemetery, and the escarpment in the vicinity of Lake Gardno), in which she described as few as 31 flowering ivy plants.

The number of localities in the Grunwald district exceeded even the number of localities described by Ć wikliński (1974) in the entire former Szczecin province. During field investigations, the cited author inventoried 19 localities of fruit-bearing ivy in forested areas as well as 152 localities in anthropogenic sites, of which a total of 407 specimens were growing on trees and 49 on buildings. Among the anthropogenic localities, 61 were found in parks and gardens, 51 on cemeteries, while 40 in towns - on buildings and over walls.

Both in the Poznan-Grunwald district and the other above mentioned towns, tree trunks constituted the most common support for climbing shoots of ivy. In Poznań fruit tree species growing in home gardens predominated. In Wrocław, Warsaw, Szczecin, Barlinek and Gardna Wielka, forest and ornamental species were dominant (Ś w i erk o s z, 1994a; Z a le s ka, 1994, 1995; Nowak, 1998; Zi el i ński, 1998; B acieczko et al. 2000, Kreft, 2006). In the right-bank Grunwald district and in Szczecin ( $\mathrm{No}$ w a k, 1998; Zi e li ń s k i, 1998), frequent supports were also walls of housing or non-housing buildings as well as fences.

The described studies from the Grunwald district, similarly as in Wrocław, confirmed the observation by C z e k a ls k i (1992) that under advantageous light conditions ivy does not need a specific height to enter the generative stage. In both cities, flowering and fruitbearing specimens were found with a height of max. $1 \mathrm{~m}$. Moreover, in Poznań no dependence was found between the geographical directions and blooming of ivy, observed by Ć w i k li ńs k i (1974).

In Wrocław flowering ivy was recorded in habitats ranging from medium- and strongly transformed, i.e. meso-, eu- and polyhemerobic; on cemeteries, in the park and forest complexes. In the Grunwald district of Poznan, euhemerobic habitats predominated in the garden-residential complex, which is connected with the residential character of this district.

Among all flowering ivy specimens recorded in the Grunwald district of Poznań, in terms of the shoot circumference, six specimens growing in the Górczyn Cemetery qualified to be protected as nature monuments. They grow on localities nos. 332, 335, 336, 340,353 and 354. Their shoots reached 30, 32, 36, 35, 47 and $51 \mathrm{~cm}$ in circumference at a height of $30 \mathrm{~cm}$ from the ground.

In the Grunwald district, apart from flowering and fruit-bearing specimens of English ivy, a very high number of specimens in the vegetative stage were also observed. In the future, it will also affect changes in 
the number of localities with specimens in the generative stage. On the other hand, the number of flowering climbers was reduced in the described localities as a result of maintenance, repair, construction work, tree felling, but also as a consequence of conscious destruction of plants. Results collected from the area of only one of the five districts of Poznan suggest that among all Polish cities the biggest documented number of localities of flowering English ivy is found in the capital city of the Wielkopolska region.

\section{CONCLUSIONS}

1. The climatic conditions of Poznań promote growth and development of English ivy. Climbers perform well under urban conditions. English ivy tolerates well the anthropogenic impact on the habitats. In the Grunwald district it develops properly and very frequently it goes into the generative stage.

2. In the Poznań-Grunwald district, a total of 769 flowering specimens of English ivy growing in 609 localities were inventoried. Most of them formed their own crown and were characterized by highly abundant flowering.

3. Flowering plants grew in areas exposed to anthropopressure, i.e. euhemerobic and polyhemerobic habitats.

4. Stem circumference of 6 specimens growing in the Górczyn Cemetery classifies them as qualifying to be nature monuments.

\section{REFERENCES}

Bacieczko W., Przybylski G., Jurzyk S. 2000. Kwitnące okazy bluszczu pospolitego (Hedera helix L.) w Barlinku (województwo zachodniopomorskie). / Flowering specimens of common ivy (Hedera helix L.) in Barlinek (West Pomerania province). Rocz. Dendrol. 48: 101-111 (in Polish).

Białobok S., Hellwig Z. (eds.). 1955. Drzewoznawstwo. Państwowe Wydawnictwo Rolnicze i Leśne, Warszawa: 473-475 (in Polish).

B oratyńska K. 1987. Kwitnące i owocujące okazy Hedera helix L. w Polsce. / Flowering and fructifying specimens of Hedera helix L. in Poland. Arbor. Kórn. 32: 19-36 (in Polish)

B ożek A. 1979. Naturalne stanowisko owocującego bluszczu Hedera helix L. w Jurze Krakowsko-Częstochowskiej. / Natural locality of generative specimens of ivy Hedera helix L. in Jura Krakowsko-Częstochowska. Chrońmy Przyr. Ojcz. 35 (6): 42-45 (in Polish).

Browicz K., Gostyńska-Januszewska M. 1969. Hedera helix L. Bluszcz pospolity. / Hedera helix L. English ivy. [In]: S. Białobok, K. Browicz (eds.). Atlas rozmieszczenia drzew i krzewów w Polsce. Zakład Dendrologii i Arboretum Kórnickie Polskiej Akademii Nauk, Poznań 8: 29-32 (in Polish).
Bugała W., Chylarecki H., Bojarczuk T. 1984. Dobór drzew i krzewów do obsadzania ulic i placów $\mathrm{w}$ miastach $\mathrm{z}$ uwzględnieniem kryteriów rejonizacji. / Trees and shrubs for planting of streets and squares in towns including regionalization criteria. Arbor. Kórn. 29: 35-62 (in Polish).

Czek alsk i M. 1992. Największe w Polsce stanowisko kwitnącego i owocującego bluszczu pospolitego (Hedera helix L.). / The biggest locality of generative specimens of ivy (Hedera helix L.) in Poland. Rocz. AR Pozn. 238, Ogrod. 20: 3-12 (in Polish).

Ćwikliński E. 1974. Rozmieszczenie i warunki siedliskowe owocującego bluszczu (Hedera helix L.) w województwie szczecińskim. / Distribution and habitat conditions of fruiting ivy (Hedera helix L.) in the Szczecin province. Rocz. Dendrol. 28: 5-35 (in Polish).

He g i G. 1931. Illustrierte Flora von Mitel-Europa. München: 915-925.

Jack owiak B. 1990. Antropogeniczne przemiany flory roślin naczyniowych Poznania. / Anthropogenic changes of the flora of vascular plants of Poznan. Wyd. UAM Poznań, Seria Biologia, 42: 7-105 (in Polish).

Ja ckowiak B. 1993. Atlas rozmieszczenia roślin naczyniowych w Poznaniu. Prace Zakładu Taksonomii Roślin UAM w Poznaniu. Poznań, 2: 11-17, 25-33, 178 (in Polish).

Jasiewicz A. 1951. Bluszcz. / Ivy. Chrońmy Przyr. Ojcz. 9-10: 1-11 (in Polish).

Kondracki J. 1994. Geografia Polski. Mezoregiony fizyczno-geograficzne. Wydawnictwo Naukowe PWN, Warszawa: 78-93 (in Polish).

Kondracki J. 2001. Geografia regionalna Polski. Wydawnictwo Naukowe PWN, Warszawa: 125, 138-142 (in Polish).

Kreft A. 2006. Hedera helix L. na terenie miejscowości Gardna Wielka (woj. pomorskie) / Hedera helix L. in the area of Gardna Wielka (Pomorskie Voivodeship). Słupskie Prace Biol. 3: 25-32 (in Polish).

Łę ck i W. (ed.). 2004. Wielkopolska nasza kraina. T. 1. Wyd. Kurpisz, Poznań: 212-216 (in Polish).

Łęcki W., Maluśkiewicz P. (eds.). 1998. Poznań od A do Z. Wyd. Kurpisz, Poznań: 80, 95, 98, 115, 164, 173 (in Polish).

Łukasiewicz A. 1986/1987. Bluszcz (Hedera helix L.) i jego rytmika rozwojowa w warunkach Ogrodu Botanicznego UAM w Poznaniu. / Ivy (Hedera helix L.) and its developmental rhythm under the conditions of UAM Botanical Garden in Poznań. Rocz. Dendrol. 37: 139149 (in Polish).

Meusel H., Jäger E., Rauschert S., Weinert E. 1978. Vergleichende Chorologie der Zentraleuropäischen Flora. Bd 2. Fischer, Jena.

Myczkowski S. 1954. Owocujący bluszcz w Krakowie. / Fruit bearing ivy in Cracow. Chrońmy Przyr. Ojcz. 3-4: 85-87 (in Polish).

Now a k G. 1998. Bluszcz pospolity Hedera helix L. w ogródkach i innych miejscach prawobrzeżnego Szczecina. 
/ Common ivy Hedera helix L. in house gardens and other places of the right-bank part of Szczecin. Folia Univ. Agric. Stetin. 188, Agricultura (71): 63-70 (in Polish).

Olaczek R. 1979. Owocujący bluszcz pospolity Hedera helix L. w Polsce Środkowej. / Fruit bearing common ivy Hedera helix L. in Central Poland. Chrońmy Przyr. Ojcz. 35 (5): 5-17 (in Polish).

Rocznik Statystyczny Poznania 2007. Rok XX. Urząd Statystyczny w Poznaniu: 25, 48-55 (in Polish).

Rocznik Statystyczny Województwa Wielkopolskiego 2008. Urząd Statystyczny w Poznaniu: 66-68 (in Polish).

Rozporządzenie Ministra Środowiska z dnia 9 lipca 2004 r. w sprawie gatunków dziko występujących roślin objętych ochroną (Dz. U. Nr 168, poz. 1764). / "Dziennik Ustaw" of 2004 no. 168, item 1764 (in Polish).

S e net a W. 1996. Drzewa i krzewy liściaste. / Broadleaf trees and shrubs. Wydawnictwo Naukowe PWN, Warszawa, III, D-H: 277-291 (in Polish).

Seneta W., Dolatowski J. 2008. Dendrologia. Wydawnictwo Naukowe PWN, Warszawa (in Polish).

Stachak A., Kubus M., Nowak G. 1999. Bluszcz pospolity (Hedera helix L.) na wiejskich terenach przykościelnych i cmentarzach południowej części Niziny Szczecińskiej. / English ivy (Hedera helix L.) in rural churchyards and cemeteries in the southern part of Szczecin Lowland. Rocz. Dendrol. 47: 183-196 (in Polish).

Stachak A., Kubus M., Nowak G. 2001. Bluszcz pospolity (Hedera helix L.) w części Niziny Szczecińskiej po zachodniej stronie Odry i Zalewu Szczecińskiego. / The common ivy (Hedera helix L.) of the Szczecin Lowland on the west side of the Oder and Szczecin Bay. Rocz. Dendrol. 49: 227-241 (in Polish).

Stachak A., Zieliński J. 1996. Kwitnące i owocujące okazy bluszczu pospolitego Hedera helix L. w parkach i na cmentarzach Szczecina. / Blooming and fruit-bearing individuals of common ivy Hedera helix $\mathrm{L}$. in parks and cemeteries of Szczecin. Zesz. Nauk. AR Szczec. Roln. Ser. Przyr. 170, (61): 35-47 (in Polish).

Szafer W. 1964. Ogólna geografia roślin. Państwowe Wydawnictwo Naukowe Warszawa: 253-254 (in Polish).

Świerkosz K. 1994a. Bluszcz pospolity (Hedera helix L.) we Wrocławiu. / The ivy (Hedera helix L.) in Wrocław. Rocz. Dendrol. 42: 37-47 (in Polish).

Świerkosz K. 1994b. Naturalne stanowiska kwitnącego bluszczu Hedera helix w okolicy Wrocławia. / Natural localities of generative specimens of ivy Hedera helix
L. near Wrocław. Chrońmy Przyr. Ojcz. 2 (49): 82-85 (in Polish).

Ustawa o ochronie przyrody z dnia 16 kwietnia 2004 r. (Dz. U. z 2004 r., nr 92, poz. 880) / the official Journal of Law „Dziennik Ustaw” of 2004 no. 92, item 880 (in Polish).

Woś A. 1994. Klimat Niziny Wielkopolskiej. Wyd. Nauk. UAM, Poznań: 1-192 (in Polish).

Zaleska J. 1994. Stanowiska owocującego bluszczu pospolitego (Hedera helix L.) na terenie centralnej Warszawy. / The stands of fructiferous ivy (Hedera helix L.) in the central parts of Warsaw. Rocz. Dendrol. 42: 125-128 (in Polish).

Zaleska J. 1995. Jeszcze o kwitnących i owocujących bluszczach pospolitych (Hedera helix L.). / Once more on fructiferous ivy (Hedera helix L.). Rocz. Dendrol. 43: 175-179 (in Polish).

Zieliński J. 1998. Kwitnące i owocujące okazy bluszczu pospolitego Hedera helix L. w ogrodach lewobrzeżnego Szczecina. / The flowering and fruit-bearing individuals of common ivy Hedera helix L. in gardens of left-bank Szczecin. Folia Univ. Agric. Stetin. 188, Agricultura (71): 71-85 (in Polish).

\section{Kwitnące rośliny \\ bluszczu pospolitego (Hedera helix L.) w dzielnicy Grunwald miasta Poznania}

\section{Streszczenie}

W okresie od września 2008 do lipca 2009 roku na terenie dzielnicy Grunwald w Poznaniu zlokalizowano 609 stanowisk kwitnącego bluszczu pospolitego, na których opisano 769 roślin. Występowały one na różnych siedliskach, w większości euhemerobowych. Najwięcej kwitnących okazów znaleziono w ogrodach przydomowych. Podporę dla pnączy stanowiły głównie drzewa i krzewy, a wśród nich drzewa owocowe - grusze i jabłonie. Z pozostałych gatunków drzew najliczniejszą grupę stanowiły: sosna pospolita, brzoza brodawkowata, modrzew europejski i robinia biała. Innymi podporami były ogrodzenia, budynki i elementy małej architektury. Bardzo duża stwierdzona liczba okazów w stanie generatywnym na terenie dzielnicy Grunwald świadczy o dużej popularności, a jednocześnie o bardzo dobrym przystosowaniu bluszczu nie tylko do warunków klimatycznych miasta Poznania, ale również do zmian wywołanych działalnością człowieka. 